RESEARCH NOTE

\title{
An endemic anuran and a horny toad: distributional histories, the potential for sympatry, and implications for conservation
}

\author{
VERNON C. BLEICH*
}

Department of Natural Resources and Environmental Science, University of Nevada Reno, Mail Stop 186, 1664 North Virginia Street, Reno, NV 89557, USA

*Corresponding Author: vcbleich@gmail.com

Key words: Amargosa River, Anaxyrus nelsoni, Anaxyrus woodhousii, Bufo nelsoni, Bufo woodhousii, genetic introgression, Great Basin, hybridization, introduced species, Oasis Valley

The Amargosa toad (Anaxyrus nelsoni) is one of five bufonid species with highly restricted distributions in the Great Basin of California and Nevada (Gordon et al. 2017, 2020), and was described as Bufo boreas nelsoni by Stejneger (1893). The holotype (USNM 18742) and 7 paratypes were collected in Oasis Valley, Nye County, Nevada. Two paratypes (USNM 18744 and USNM 18745) originally ascribed to that taxon were collected in the Amargosa River drainage at Resting Springs, Inyo Co., California, but the taxonomic status of the Resting Springs paratypes appears uncertain (Storer 1925). The Amargosa toad is restricted in distribution to Oasis Valley (Burroughs 1999; Dodd 2013; IUCN 2019) where it occupies wetlands along or adjacent to a $15-\mathrm{km}$ reach of the Amargosa River between Springdale and Beatty (Fig. 1). The taxon may be declining in number (Simandle 2006, IUCN 2019), but is not protected under the federal endangered species act (USFWS 2010). Following population assessments (Altig and Dodd 1987; Heinrich 1995; Stein et al. 2000), which generated concern about conservation of the taxon, a multi-party agreement (NDOW 2000) was developed. The most recent status assessments of the Amargosa toad (Hammerson 2004; USFWS 2010), however, were completed more than a decade ago. In this paper I do not advocate for endangered or threatened status for Amargosa toad but, rather, offer a cautionary note in the context of the potential for sympatry between $A$. nelsoni and a nonnative congener, Woodhouse's toad (Anaxyrus woodhousii), and the consequences thereof.

Woodhouse's toad is well-adapted to a variety of ecological conditions (Bradford et al. 2005; Ryan et al. 2017), and occurs widely throughout the United States (Conant 1958; Stebbins 2003). In California, its historical range was restricted to the Lower Colorado River Valley, Imperial County (Storer 1925), and historical range in Nevada encompassed the floodplains of the Muddy, Virgin, and Colorado rivers in Clark County (Bradford et al. 2005). This generalist bufonid is highly successful at exploiting newly available habitat and, over the past century, this ability has led to a substantial expansion of its distribution in California and Nevada (Bradford et al. 2005; Goodward and Wilcox 2019; Bleich 2020). 


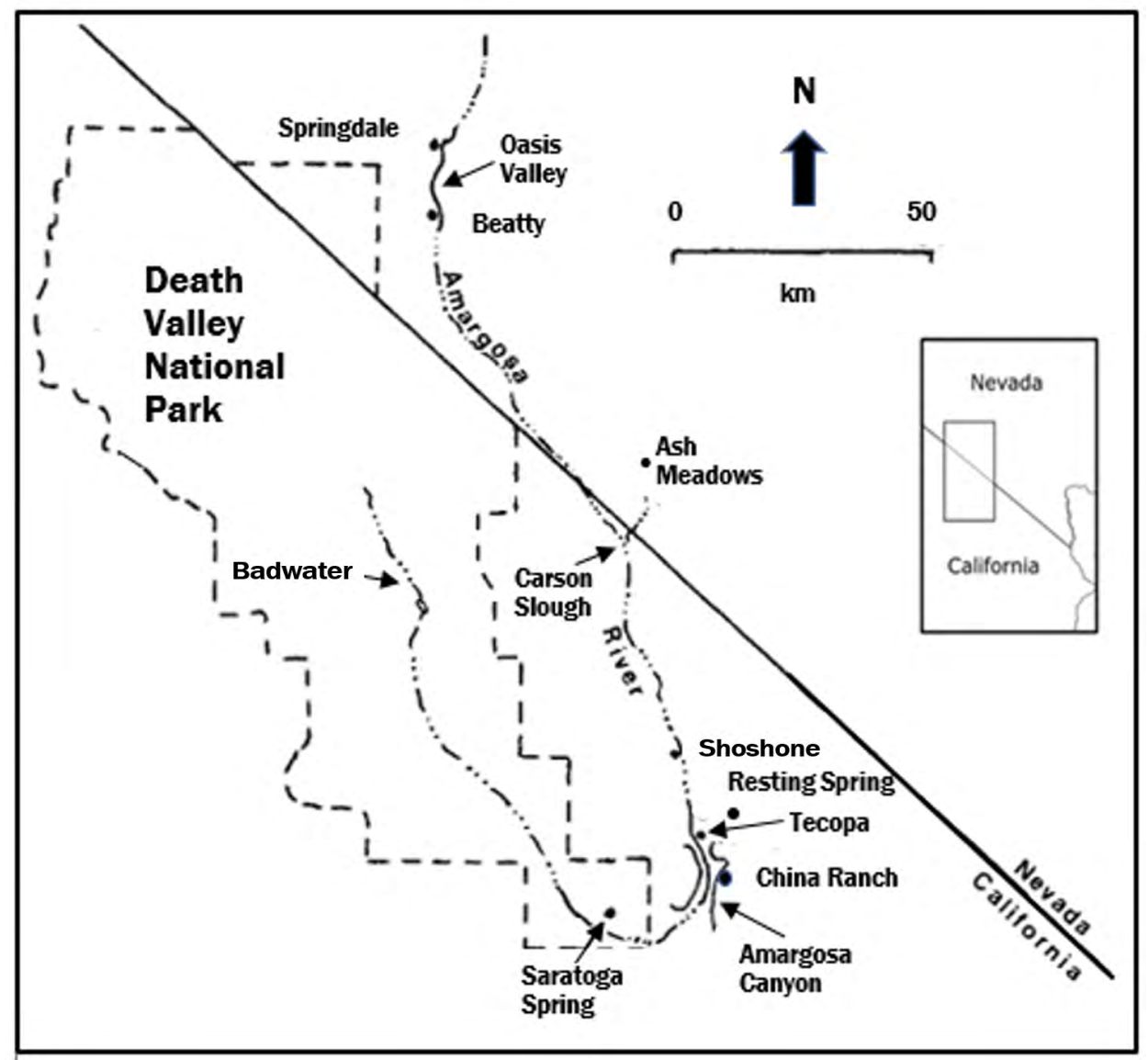

Figure 1. The Amargosa River has its origin at an elevation of 1,200 m on Pahute Mesa, about $20 \mathrm{~km}$ north of Beatty, Nye County, Nevada. The river flows southward, westward, and then northward over a distance of $185 \mathrm{~km}$, reaching its terminus near Badwater in Death Valley, Inyo County, California. Sections of the Amargosa River that do not support perennial surface flows in the absence of substantial rainfall events are indicated by the broken line; those sections normally supporting surface water occur primarily in Oasis Valley, in the vicinity of the Amargosa River Canyon, and near Saratoga Spring, and are indicated by a solid line; adapted from Williams et al. (1984).

In general, amphibian movements are occasional and limited (Sinsch 1990; Blaustein et al. 1994), but long-distance dispersal by anurans may be more common than historically assumed, in part because logistical realities often limit the size of study areas (Smith 2003). Further, the distances over which specific taxa can disperse often are poorly known (Smith and Green 2006), but long-distance movements by many species of bufonids have been described, and A. woodhousii - as well as a number of other congenerics - is capable of such movements (Smith and Green 2005, 2006; Palmeri-Miles 2012; Bleich 2020; Myers 2020). Expansion of the distribution of $A$. woodhousii in California and Nevada can be explained in large part by anthropogenic introductions, or other anthropogenic actions that have created suitable habitat (Bradford et al. 2005; Goodward and Wilcox 2019). In addition, severe precipitation events likely have provided opportunities for $A$. woodhousii to 
move long distances along intermittent waterways and colonize areas not contiguous with extant populations (Bleich 2020). Rainfall events similar in severity to those described by Bleich (2020) occur within the historical range of A. nelsoni, and further south along the Amargosa River (Tanko and Glancy 2001; WRCC 2020). Water flows above ground in and adjacent to the Amargosa River (Fig. 1, Fig. 2) for extended periods following such events (Tanko and Glancy 2001) and, although some sections dry spatially and temporally, other stretches remain wet year-round (Dodd 2013; Humphrey et al. 2017).

Numerous records of $A$. woodhousii recently have been confirmed along the Amargosa River, and elsewhere in the Amargosa River drainage basin, in Inyo and San Bernardino counties, California and Nye County, Nevada. In 2012, A. woodhousii was reported from an undisclosed location along the Amargosa River "south of Death Valley" (California Herps 2020a), and the species later was reported from wetlands along the Amargosa River $\sim 5 \mathrm{~km}$ south of Tecopa, Inyo County (Greene and Branston 2013). Information provided initially by California Herps (2020a) was revised (California Herps 2020b) after the location was confirmed (G. Nafis, in litt., 20 July 2020) to be that reported by Greene and Branston (2013). Observations (iNaturalist 2020) or museum specimens obtained in 2017 (VertNet 2020) confirmed persistence of the population described by Greene and Branston (2013), as well as additional locations along the Amargosa River. Further, A. woodhousii has become established in a reservoir and in wetlands along Willow Creek, a tributary to the Amargosa River near the China Ranch, in northern San Bernardino County and southern Inyo County (Appendix A). Greene and Branston (2013) estimated the Euclidean distance from their

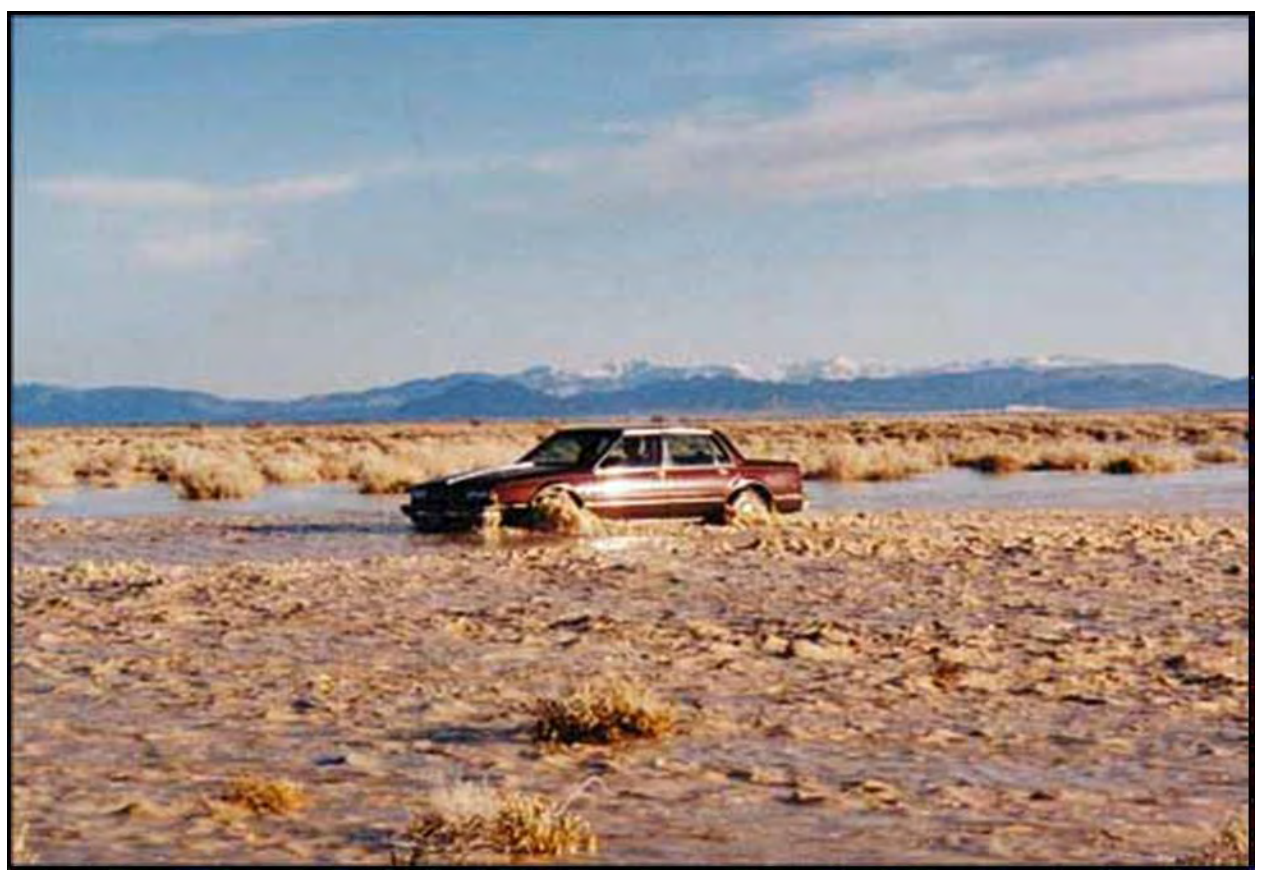

Figure 2. Extreme precipitation events in the Amargosa River drainage basin frequently result in temporary wetlands that can serve as 'stepping-stone' habitat and facilitate dispersal by Anaxyrus woodhousii. This image depicts flooding on State Line Road at Carson Slough near Death Valley Junction, Inyo County, California, on 25 February 1998; adapted from Tanko and Glancy (2001). 
recently discovered population of $A$. woodhousii to the nearest population of $A$. nelsoni to be $130 \mathrm{~km}$. As of 2017, the Path Distance Function in Google Earth Pro indicated the distance between the nearest population of $A$. woodhousii on the Amargosa River to that of $A$. nelsoni in Oasis Valley was approximately $150 \mathrm{~km}$ as measured along the river channel. Nevertheless, in 2016, 2019, and 2020, Woodhouse's toad was confirmed at Ash Meadows National Wildlife Refuge (AMNWR), Nye County, an area supporting numerous springs and wetlands (Kodric-Brown and Brown 2007) and proximate to the Amargosa River. Confirmation of $A$. woodhousii at AMNWR increases the potential of its presence in the main channel of the Amargosa River at the same latitude, thereby placing it within a Euclidian distance of $\sim 70$ $\mathrm{km}(\sim 100 \mathrm{~km}$ as measured along the river channel) of populations of A. nelsoni.

Neither date(s) nor source(s) of origin of these recently confirmed populations of $A$. woodhousii can be determined with certainty. A herpetofaunal survey of the Death Valley region that included portions of California and Nevada (Stejneger 1893) yielded no records of A. woodhousii (described at the time as Bufo lentiginosus woodhousii) in the vicinity of the Amargosa River, including Saratoga Spring - a perennial source of surface water separated from the river by a damp salt flat and thin layer of water (Bradley 1970) - or elsewhere along the Amargosa River, including Oasis Valley. Norris (1949:46) confirmed the presence of treefrogs (Pseudacris regilla), and Turner and Wauer (1963) confirmed the presence of P. regilla and red-spotted toads (Anaxyrus punctatus) at Saratoga Spring, but neither party reported $A$. woodhousii at that location. Norris (1950:117-118) also reported the presence of treefrogs and of introduced bullfrogs (Lithobates catesbeianus) at Fairbanks Ranch and at Fairbank's Springs - both within AMNW and having abundant water, mesquite trees, cottonwoods, tamarisk, and grass (Norris 1950:117-118; McCracken 1990:22). Neither Norris (1950) nor McCracken (1990) mentioned the presence of toads at either of those locations. It is certain, however, that Anaxyrus sp. was collected at Resting Springs in Chicago Valley, Inyo County, in 1891 (Stejneger 1893); Resting Springs is connected to the Amargosa River by a normally dry watercourse (Hershler and Pratt 1990) of $\sim 5 \mathrm{~km}$ in length (Fig. 1).

Nearly 80 years following Stejneger's (1893) report, Bezy and Wright (1972) reported A. punctatus, but not Woodhouse's toad, during their herpetological survey of the Amargosa River Canyon. Additionally, I did not encounter Woodhouse's toad during extensive fieldwork along the Amargosa River between Willow Creek and Shoshone (Bleich 1972, 1974, 1979, 1980; Gould and Bleich 1977). Further, F. A. Gomez (in litt., 7 September 2020), a resident of Tecopa from 1961 to 1985, does not recall observing any toads during countless hours spent recreating along the Amargosa River. Moreover, and roughly a century after Stejneger's (1893) report, neither Pratt and Hoff (1992) nor Persons and Nowak (2006) reported A. woodhousii in the Amargosa River drainage. Thus, available evidence suggests that Woodhouse's toad had not become established in that region prior to the work of Persons and Nowak (2006).

Whether the current distribution of $A$. woodhousii in the Amargosa River drainage represents multiple anthropogenic introductions, or is the result of range expansion from a single introduction, is not known. It is possible that Woodhouse's toad was present at one or more of these sites (Appendix A) prior to 2012, but the initial date(s) of any such appearance(s) cannot be ascertained, and the presence of $A$. woodhousii in the Amargosa River drainage is most apt to be a recent phenomenon. The ability of Woodhouse's toad to disperse along normally dry streambeds confirms it can move substantial distances when surface flows create suitable, albeit perhaps temporary, 'stepping stone' habitat (Bleich 2020), and such may contribute to an expanding distribution of $A$. woodhousii in the Amargosa River drain- 
age and elsewhere. Stepping-stone habitat enhances the probability of dispersal into areas of noncontiguous - albeit otherwise suitable - habitat that can arise as a result of stochastic occurrences, among which are extreme rainfall events. Further, these habitat patches have allowed expansion of $A$. woodhousii (and other anurans) into previously unoccupied areas (Goodward and Wilcox 2019). Stepping-stone habitat also has the potential to promote gene flow among isolated populations, potentially enhancing persistence of recently established, but noncontiguous, demographic units (Bleich et al. 1990).

Anaxyrus spp. are especially vulnerable to congeneric hybridization, and interbreeding between Woodhouse's toad - a highly successful species capable of rapid or long-distance dispersal under suitable conditions - and $\geq 10$ other bufonids has posed a conservation risk to several taxa (Hillis et al. 1984; Sullivan and Lamb 1988; Gergus et al. 1999; Lannoo 2005). If Woodhouse's toad becomes sympatric with $A$. nelsoni, the ramifications for disease transmission, ecological relationships (i.e., competition), hybridization and resultant genetic introgression (Fig. 3), or behavioral modifications, singly or in combination, bode poorly for the future of Amargosa toad as a viable taxon (Carey et al. 2003; Sullivan 2005).

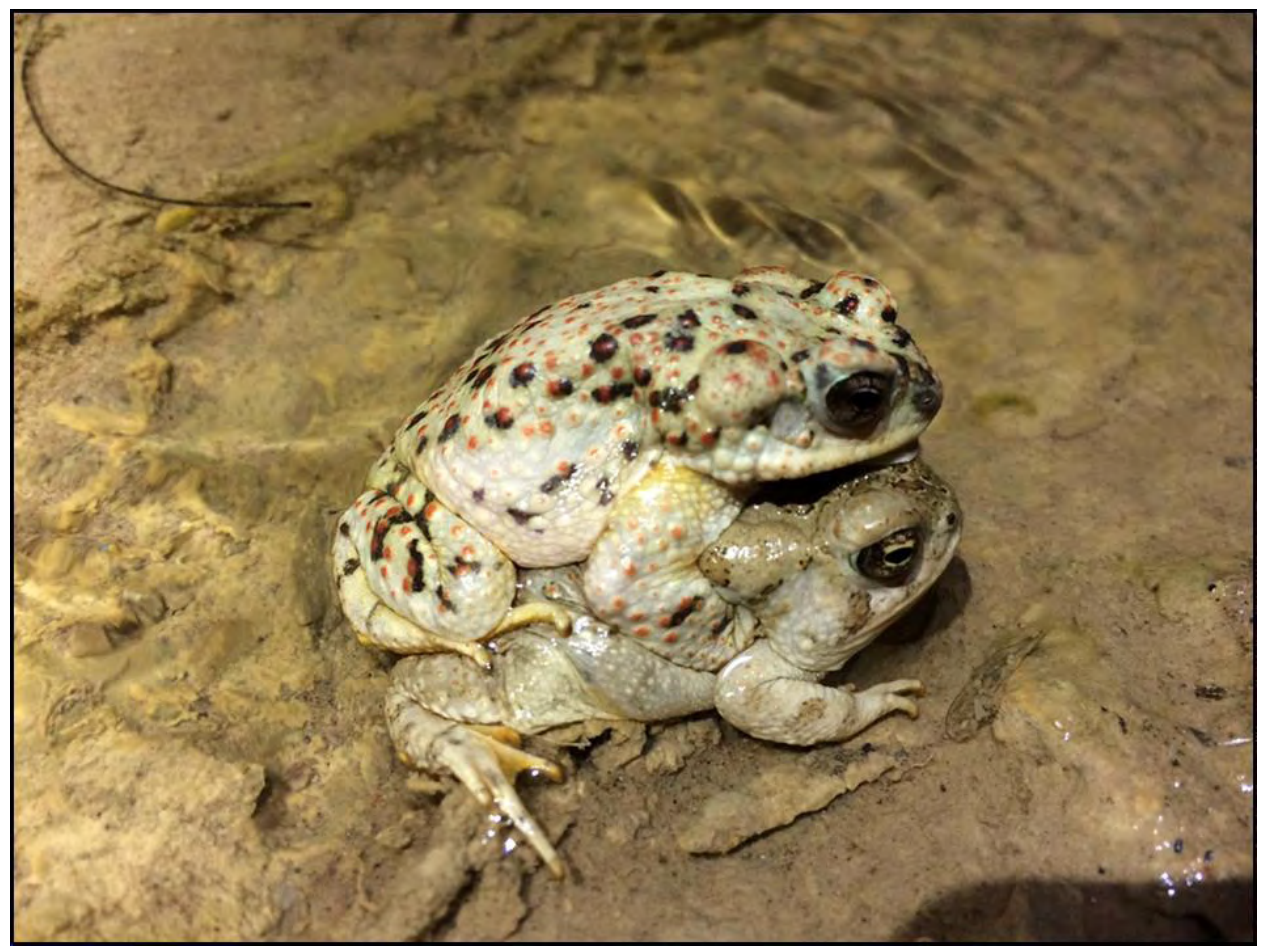

Figure 3. Woodhouse's toad (Anaxyrus woodhousii) has hybridized with at least 10 other species in the western United States as summarized by Sullivan (2005), and readily breeds with other members of the family Bufonidae as demonstrated here with a red-spotted toad (Anaxyrus punctatus). If Woodhouse's toad attains sympatry with Amargosa toad (Anaxyrus nelsoni), the potential for genetic introgression will become a primary conservation concern. Photograph (C) B. J. Putman, 6 April 2017, China Ranch, San Bernardino County, California; used with permission. 
The recent and continuing de-emphasis of natural history as a respectable scientific discipline by many colleges and universities (Noss 1996; Kessler and Booth 1998; Bleich and Oehler 2000; Bleich 2018) has yielded decreased interest in the relevance of descriptive ecology or distributional records. Citizen science, however, is beginning to fill that void, and increasingly is recognized as a valued and valid source of information (Gura 2013; Ballard et al. 2017; Spear et al. 2017; Parker et al. 2018b). It is through such efforts that shifts in the distribution of $A$. woodhousii along the Amargosa River (iNaturalist 2020) and elsewhere (Goodward and Wilcox 2019), or documentation of the western toad (Anaxyrus boreas) in the Amargosa River drainage (iNaturalist 2020) recently have become available or are tractable, but shortcomings do exist. For example, while emphasizing the value of the riparian ecosystem associated with the Amargosa River and its importance to a variety of taxa, Parker et al. (2018a) failed to note that $A$. woodhousii is not native to that system or to call attention to the ramifications of its presence.

Proximity of Woodhouse's toad to the distribution of $A$. nelsoni was noted by Greene and Branston (2013). More recently, A. woodhousii has been confirmed at multiple locations along the Amargosa River, and potentially within $100 \mathrm{~km}$ of Oasis Valley. The dispersal ability of Woodhouse's toad and the occurrence of multiple disjunct populations of this highly adaptable bufonid in the same river drainage occupied by a vulnerable congeneric raise concern and suggest additional efforts are necessary to understand the current distribution of $A$. woodhousii. Demonstrating the potential impact of an exotic or invasive species, however, need not require conclusive proof (Carey et al. 2003) before action is taken to prevent development of an egregious, and perhaps irreversible, situation. As emphasized by Bradford et al. (2005), doing so is a tremendous challenge, but fear-of-failure to preclude development of sympatry between an endemic species of limited distribution and a widespread and highly adaptable invasive species should not prevent efforts to ensure the persistence of $A$. nelsoni as a viable taxon (Meek et al. 2015). I suggest conservation agencies and interested parties - including citizen-scientists (Bass 2016) — work collaboratively to record shifts in the distribution of Woodhouse's toad along the Amargosa River and that actions to prevent the northward dispersal of $A$. woodhousii-and the potential for sympatry with $A$. nelsoni-be initiated immediately.

\section{ACKNOWLEDGMENTS}

I thank C. T. Collins (California State University Long Beach [CSULB]), and J. A. St. Amant, E. P. Pister, G. I. Gould, J. R. Gustafson, R. H. Davidson, and C. S. Edon (California Department of Fish and Game [CDFG]) for encouraging my long-term interest in the Amargosa River drainage; G. I. Gould and R. L. Vernoy (CDFG), P. D. Jorgensen (California Department of Parks and Recreation), O. A. Schwartz (CSULB), and B. and S. Peterson (Wildlife Research Photography) for assistance with field work; B. Brown for access to private property; and F. A. Gomez for sharing his detailed knowledge of the Amargosa River Canyon. I thank G. B. Pauly (Los Angeles County Museum of Natural History), K. Guadalupe (Nevada Department of Wildlife), A. Kleinhesselink (University of California Los Angeles), and B. J. Putman (California State University San Bernardino), who participated in the Amargosa River Expert Bioblitz (Parker et al. 2017) and collected specimens or recorded observations of $A$. woodhousii, and for ensuring information was available in searchable databases; B. J. Putman for permission to use the photograph in Figure 3; G. Nafis for clarification of locations published in California Herps (2020a, 2020b); and L. 
Greene (CDFG) for correspondence and conversations regarding the potential sources of A. woodhousii initially documented in the Amargosa River drainage basin. I also thank two anonymous reviewers for helpful comments that improved the manuscript. My early work in the Amargosa River watershed was funded in part by a travel grant from the El Dorado Chapter of the National Audubon Society, and later by CDFG Federal Aid in Wildlife Restoration Projects W-26-D (Wildlife Habitat Development) and W-54-R (Special Wildlife Investigations). Manuscript preparation was supported by the Eastern Sierra Center for Applied Population Ecology. This is Professional Paper 136 from the Eastern Sierra Center for Applied Population Ecology.

\section{LITERATURE CITED}

Altig, R., and C. K. Dodd, Jr. 1987. The status of the Amargosa toad (Bufo nelsoni) in the Amargosa River drainage of Nevada. Southwestern Naturalist 32:276-278.

Ballard, H. L., L. D. Robinson, A. N. Young, G. B. Pauly, L. M. Higgins, R. F. Johnson, and J. C. Tweddle. 2017. Contributions to conservation outcomes by natural history museum-led citizen science: examining evidence and next steps. Biological Conservation 208:87-97.

Bass, J. 2016. Herping regulations for states in the southwestern regions, part 2: California. Southwestern Center for Herpetological Research Bulletin 6:77-82.

Bezy, R. L., and J. W. Wright. 1972. Amphibians and reptiles of the Tecopa-Dumont Dunes area. Pages 89-94 in M. A. Romero, editor. Amargosa Canyon-Dumont Dunes proposed natural area. House of Impressions, Sun Valley, CA, USA.

Blaustein, A. R., D. B. Wake, and W. B. Sousa. 1994. Amphibian declines: judging stability, persistence, and susceptibility of populations to local and global extinctions. Conservation Biology 8:60-71.

Bleich, V. C. 1972. An annotated checklist of the mammals occurring in the Tecopa-Dumont Sand Dunes study area. Appendix (Part I) in M. A. Romero, editor. Amargosa Canyon-Dumont Dunes proposed natural area. House of Impressions, Sun Valley, CA, USA.

Bleich, V. C. 1974. Muskrats (Ondatra zibethicus) in Amargosa Canyon, Inyo and San Bernardino counties, California. Murrelet 55:7-8.

Bleich. V. C. 1979. Microtus californicus scirpensis not extinct. Journal of Mammalogy 61:851-852.

Bleich, V. C. 1980. Amargosa vole study. Nongame Wildlife Investigations Job Final Report, Federal Aid in Wildlife Restoration Project W-54-R-10. California Department of Fish and Game, Sacramento, CA, USA.

Bleich, V. C. 2018. Maintaining momentum for conservation: bighorn sheep as an example. Wildlife Society Bulletin 42:540-546.

Bleich, V. C. 2020. Locality records for Woodhouse's toad: have wet washes in a dry desert led to extralimital occurrences of an adaptable anuran? California Fish and Wildlife 106:258-266.

Bleich, V. C., and M. W. Oehler. 2000. Wildlife education in the United States: thoughts from agency biologists. Wildlife Society Bulletin 28:542-545.

Bleich, V. C., J. D. Wehausen, and S. A. Holl. 1990. Desert-dwelling mountain sheep: conservation implications of a naturally fragmented distribution. Conservation Biology 4:383-390. 
Bradford, D. F., J. R. Jaeger, and S. A. Shanahan. 2005. Distributional changes and population status of amphibians in the eastern Mojave Desert. Western North American Naturalist 65:462-472.

Bradley, W. G. 1970. The vegetation of Saratoga Springs, Death Valley National Monument, California. Southwestern Naturalist 15:111-129.

Burroughs, M. 1999. Making room for the Amargosa toad. Endangered Species Bulletin 24(5):10-11.

California Herps. 2020a. Rocky Mountain Toad-Anaxyrus woodhousii woodhousii. Available at: http://www.californiaherps.com/frogs/pages/a.w.woodhousii.html (February 2020).

California Herps. 2020b. Rocky Mountain Toad-Anaxyrus woodhousii woodhousii. Available at: http://www.californiaherps.com/frogs/pages/a.w.woodhousii.html (August 2020).

Carey, C., D. F. Bradford, J. L. Brunner, J. P. Collins, E. W. Davidson, J. E. Longcore, M. Ouellet, A. P. Pessier, and D. M. Schock. 2003. Biotic factors in amphibian declines. Pages 153-208 in G. Linder, S. K. Krest, and D. W. Sparling, editors. Amphibian declines: an integrated analysis of multiple stressor effects. Society of Environmental Toxicology and Chemistry, Pensacola, FL, USA.

Conant, R. 1958. A Field Guide to Reptiles and Amphibians of the United States and Canada East of the 100th Meridian. Houghton Mifflin Company, Boston, MA, USA.

Dodd, C. K. 2013. Frogs of the United States and Canada. Johns Hopkins University Press, Baltimore, MD, USA.

Gergus, E.W. A., K. B. Malmos, and B. K. Sullivan. 1999. Natural hybridization among distantly related toads (Bufo alvarius, B. cognatus, and B. woodhousii) from central Arizona. Copeia 1999:281-286.

Goodward, D. M., and M. D. Wilcox. 2019. The Rio Grande leopard frog (Lithobates berlandieri) and other introduced and native herpetofauna of the Coachella Valley, Riverside County, California. California Fish and Game 105:48-71.

Gordon, M. R., E. T. Simandle, and C. R. Tracy. 2017. A diamond in the rough desert shrublands of the Great Basin in the western United States: a new cryptic toad species (Amphibia: Bufonidae: Bufo [Anaxyrus]) discovered in northern Nevada. Zootaxa 4290(1):123-139.

Gordon, M. R., E. T. Simandle, F. C. Sandmeier, and C. R. Tracy. 2020. Two new cryptic endemic toads of Bufo discovered in central Nevada, western United States (Amphibia: Bufonidae: Bufo [Anaxyrus]). Copeia 108:166-183.

Gould, G. I., and V. C. Bleich. 1977. Amargosa vole study: progress report. Nongame Wildlife Investigations Job Progress Report, Federal Aid in Wildlife Restoration Project W-54-R-10. California Department of Fish and Game, Sacramento, CA, USA.

Greene, L., and T. Branston. 2013. Anaxyrus woodhousii woodhousii (Rocky Mountain toad). Herpetological Review 44:270.

Gura, T. 2013. Citizen science: amateur experts. Nature 496 (7444):259-261.

Hammerson, G. 2004. Anaxyrus nelsoni. The IUCN red list of threatened species 2004: e.T3181A9661222. Available from: https://dx.doi.org/10.2305/IUCN.UK.2004. RLTS.T3181A9661222.en (July 2020).

Heinrich, J. H. 1995. Summary of August 28-31, 1995 surveys for the Amargosa toad, Bufo nelsoni. Nevada Division of Wildlife, Las Vegas, NV, USA. 
Hershler, R., and W. L. Pratt. 1990. A new Pyrgulopsis (Gastropoda: Hydrobiidae) from southeastern California, with a model for historical development of the Death Valley hydrographic system. Proceedings of the Biological Society of Washington 103:279-299.

Hillis, D. M., A. M. Hillis, and R. F. Martin. 1984. Reproductive ecology and hybridization of the endangered Houston toad (Bufo houstonensis). Journal of Herpetology $18: 56-72$.

Humphrey, K. G., J. B. Leavitt, W. J. Goldsmith, B. R. Kesner, and P. C. Marsh. 2017. Distribution of Amargosa River pupfish (Cyprinodon nevadensis amargosae) in Death Valley National Park, California. California Fish and Game 103:91-95.

iNaturalist. 2020. Anaxyrus woodhousii. Available at https://www.inaturalist.org (July 2020).

IUCN (International Union for the Conservation of Nature). 2019. The IUCN red list of threatened species. Version 2019-3. Available from: https://www.iucnredlist.org/ search?query=anaxyrus\%20nelsoni\&searchType=species (February 2020).

Kessler, W. B., and A. L. Booth. 1998. Professor Leopold, what is education for? Wildlife Society Bulletin 26:707-712.

Kodric-Brown, A., and J. H. Brown. 2007. Native fishes, exotic mammals, and the conservation of desert springs. Frontiers in Ecology and the Environment 5:549-553.

Lannoo, M. (editor). 2005. Amphibian Declines: The Conservation Status of United States Species. University of California Press, Berkeley, CA, USA.

McCracken, R. D. 1990. An interview with Celesta Lisle Lowe. Nye County Town History Project, Nye County Commissioners, Tonopah, NV, USA. Available from: http:// pahrumpvalleymuseum.org/lowe/lowe.pdf (August 2020).

Meek, M. H., C. Wells, K. M. Tomalty, J. Ashander, E. M. Cole, D. A. Gille, B. J. Putman, J. P. Rose, M. S. Savoca, L. Yamane, J. M. Hull, D. L. Rogers, E. B. Rosenblum, S. F. Shogren, R. R. Swaisgood, and B. May. 2015. Fear of failure in conservation: the problem and potential solutions to aid conservation of extremely small populations. Biological Conservation 184:209-217.

Menges, C. M. 2008. Multistage late Cenozoic evolution of the Amargosa River drainage, southwestern Nevada and eastern California. Special Paper of the Geological Society of America 439:39-90.

Myers, A. K. 2020. Toadal isolation: genetic connectivity of the western toad (Anaxyrus boreas) along I-90 in the Snoqualmie Pass area of Washington state. Thesis, Central Washington University, Ellensburg, WA, USA.

NDOW (Nevada Division of Wildlife). 2000. Conservation agreement for the Amargosa toad (Bufo nelsoni) and co-occurring sensitive species in Oasis Valley, Nye County, Nevada. Nevada Division of Wildlife, Reno, NV, USA.

Norris, K. S. 1949. Kenneth S. Norris field notes 1949-1993. Special Collections and Archives, University of California, Santa Cruz, USA. Available from: http:/cdn. calisphere.org/data/13030/x7/c8pc36x7/files//NorrisFieldNoteTypescripts.pdf (August 2020).

Norris, K. S. 1950. Kenneth S. Norris field notes 1949-1993. Special Collections and Archives, University of California, Santa Cruz, USA. Available from: http://cdn. calisphere.org/data/13030/x7/c8pc36x7/files//NorrisFieldNoteTypescripts.pdf (August 2020). 
Noss, R. F. 1996. The naturalists are dying off. Conservation Biology 10:1-3.

Palmeri-Miles A. 2012. Seasonal movement patterns and overwintering of western toads (Anaxyrus boreas) near Snoqualmie Pass, Washingon. Thesis, Central Washington University, Ellensburg, WA, USA.

Parker, S. S., B. S. Cohen, N. Fraga, B. Brown, J. Cole, W. Chatfield-Taylor, K. Guadalupe, G. B. Pauly, D. Cooper, and M. Ordenana. 2017. Amargosa River expert bioblitz. The Nature Conservancy, Los Angeles, CA, USA.

Parker, S. S., J. Moore, and L. Warren. 2018a. Ecological values of the Amargosa River in California. The Nature Conservancy, Los Angeles, CA, USA.

Parker, S. S., G. B. Pauly, J. Moore, N. S. Fraga, J. J. Knapp, Z. Principe, B. V. Brown, J. M. Randall, B. S. Cohen, and T. A. Wake. 2018b. Adapting the bioblitz to meet conservation needs. Conservation Biology 32:1007-1019.

Persons, D. B., and E. M. Nowak. 2006. Inventory of amphibians and reptiles at Death Valley National Park. USGS Southwest Biological Science Center, Colorado Plateau Research Station, Flagstaff, AZ, USA.

Pratt, W. L., and K. Hoff. 1992. Aquatic invertebrate and amphibian survey of Saratoga Springs, Travertine Springs, and Amargosa River in Death Valley National Monument. Unpublished report prepared for the National Park Service. Museum of Natural History, University of Nevada, Las Vegas, NV, USA.

Ryan, M. J., J. T. Giermakowski, I. M. Latella, and H. L. Snell. 2017. No evidence of hybridization between the Arizona toad (Anaxyrus microscaphus) and Woodhouse's toad (A. woodhousii) in New Mexico, USA. Herpetological Conservation and Biology 12:565-575.

Simandle, E. T. 2006. Population structure and conservation of two rare toad species (Bufo exsul and Bufo nelsoni) in the Great Basin, USA. Dissertation, University of Nevada, Reno, NV, USA.

Sinsch, U. 1990. Migration and orientation in anuran amphibians. Ethology, Ecology, and Evolution 2:65-79.

Smith, M. A. 2003. Spatial ecology of Bufo fowleri. Ph.D. dissertation, McGill University, Montreal, Quebec, Canada.

Smith, M. A., and D. M. Green. 2005. Dispersal and the metapopulation paradigm in amphibian ecology and conservation: are all amphibian populations metapopulations? Ecography 28:110-128.

Smith, M. A., and D. M. Green. 2006. Sex, isolation and fidelity: unbiased long-distance dispersal in a terrestrial amphibian. Ecography 29:649-658.

Spear, D. M., G. B. Pauly, and K. Kaiser. 2017. Citizen science as a tool for augmenting museum collection data from urban areas. Frontiers in Ecology and Evolution 5:86.

Stebbins, R. C. 2003. A Field Guide to Western Reptiles and Amphibians. Third edition. Houghton Mifflin Company, Boston, MA, USA.

Stein, J., B. Hobbs, and G. A. Wasley. 2000. Population monitoring of the Amargosa toad (Bufo nelsoni) and habitat evaluation in Oasis Valley, Nevada. Nevada Division of Wildlife, Las Vegas, USA.

Stejneger, L. 1893. Annotated list of the reptiles and batrachians collected by the Death Valley Expedition in 1891, with descriptions of new species. North American Fauna 7:159-228. 
Storer, T. I. 1925. A synopsis of the amphibia of California. University of California Publications in Zoology 27:1-343.

Sullivan, B. K. 2005. Bufo woodhousii Girard, 1854: Woodhouse's toad. Pages 438-440 in M. Lannoo, editor. Amphibian declines: the conservation status of United States species. University of California Press, Berkeley, CA, USA.

Sullivan, B. K., and T. Lamb. 1988. Hybridization between the toads Bufo microscaphus and Bufo woodhousii in Arizona: variation in release calls and allozymes. Herpetologica 44:325-333.

Tanko, D. J., and P. A. Glancy. 2001. Flooding in the Amargosa River Drainage Basin, February 23-24, 1998, southern Nevada and eastern California, including the Nevada Test Site. USGS Fact Sheet 036-01. U.S. Geological Survey, Carson City, NV, USA.

Turner, F. B., and R. H. Wauer. 1963. A survey of the herpetofauna of the Death Valley area. Great Basin Naturalist 23:119-128.

USFWS (U.S. Fish and Wildlife Service). 2010. Endangered and threatened wildlife and plants; 12-month finding on a petition to list the Amargosa toad as threatened or endangered. Federal Register 75(138):42040-42054.

VertNet. 2020. Woodhouse's toad. Available from: http://portal.vertnet.org/search?q=spe cificepithet:woodhousii+genus:Bufo+county:\%22Inyo\%22+stateprovince:\%22 California $\% 22+$ year $+\% 3 \mathrm{E}=+2010+$ year $+\% 3 \mathrm{C}=+2020+$ institutioncode: $\mathrm{LACM}$ (July 2020).

Williams, J. E., G. C. Kobetich, and C. T. Benz. 1984. Management aspects of relict populations inhabiting the Amargosa Canyon ecosystem. Pages 706-715 in R. E. Warner and K. M. Hendrix, editors. California riparian systems: ecology, conservation, and productive management. University of California Press, Berkeley, CA, USA.

WRCC (Western Regional Climate Center). 2020. Cooperative climatological data summaries. Available from: https://wrcc.dri.edu/Climate/west_coop_summaries.php (February 2020).

Submitted 22 October 2020

Accepted 30 November 2020

Associate Editor was J. Nguyen 


\section{APPENDIX A. RECORDS OF ANAXYRUS WOODHOUSII IN THE AMARGOSA RIVER DRAINAGE}

The Amargosa River drains a watershed of 15,540 km² (Menges 2008). The river extends $\sim 198 \mathrm{~km}$ from its origin on Pahute Mesa, Nye County, Nevada, through a portion of southern Inyo and northern San Bernardino counties, California, and reaches is terminus in Death Valley, Inyo County. Within the drainage basin, and as of the date of this publication, Anaxyrus woodhousii has been confirmed in that portion of Amargosa River near Tecopa, California, and at Ash Meadows National Wildlife Refuge, Nye County, Nevada.

\begin{tabular}{|c|c|c|c|c|c|}
\hline Date & General Location & County & Latitude & Longitude & Source \\
\hline Apr 2012 & $\begin{array}{l}\text { Amargosa River, } \sim 4 \mathrm{~km} \mathrm{SSE} \\
\text { of Tecopa }\end{array}$ & Inyo $^{\text {a }}$ & 35.815919 & -116.214778 & LACM PC $1602,1603^{\mathrm{d}, \mathrm{e}}$ \\
\hline Mar 2016 & $\begin{array}{l}\text { Ash Meadows National Wild- } \\
\text { life Refuge }\end{array}$ & Nye $^{b}$ & 36.401367 & 116.274716 & iNaturalist $10173429^{\mathrm{f}}$ \\
\hline Apr 2017 & $\begin{array}{l}\text { China Ranch Reservoir, China } \\
\text { Ranch }\end{array}$ & Inyo & 35.804388 & -116.183839 & iNaturalist $5633718^{\mathrm{f}}$ \\
\hline Apr 2017 & $\begin{array}{l}\text { China Ranch Reservoir, China } \\
\text { Ranch }\end{array}$ & Inyo & 35.805131 & -116.183450 & iNaturalist $5633759^{\mathrm{f}}$ \\
\hline Apr 2017 & $\begin{array}{l}\text { China Ranch Reservoir, China } \\
\text { Ranch }\end{array}$ & Inyo & 35.804388 & -116.183839 & iNaturalist $5633770^{\mathrm{f}}$ \\
\hline Apr 2017 & $\begin{array}{l}\text { China Ranch, adjacent to main } \\
\text { parking area }\end{array}$ & Inyo & 35.799762 & -116.194764 & iNaturalist $5645084^{\mathrm{f}}$ \\
\hline Apr 2017 & $\begin{array}{l}\text { China Ranch downstream from } \\
\text { main parking area }\end{array}$ & Inyo & 35.799008 & -116.195107 & iNaturalist $5645092^{\mathrm{f}}$ \\
\hline Apr 2017 & $\begin{array}{l}\text { Amargosa River, S confluence } \\
\text { with Willow Creek }\end{array}$ & $\mathrm{SB}^{\mathrm{c}}$ & 35.783139 & -116.201470 & iNaturalist $5645123^{\mathrm{f}}$ \\
\hline Apr 2017 & $\begin{array}{l}\text { Amargosa River, } 4.2 \text { km S Old } \\
\text { Spanish Trail Hwy }\end{array}$ & Inyo & 35.814089 & -116.210463 & iNaturalist $5712521^{\mathrm{f}}$ \\
\hline Apr 2017 & $\begin{array}{l}\text { Amargosa River, } 4.0 \mathrm{~km} \mathrm{~S} \text { Old } \\
\text { Spanish Trail Hwy }\end{array}$ & Inyo & 35.815352 & -116.21093 & iNaturalist $5633669^{\mathrm{f}}$ \\
\hline Apr 2017 & $\begin{array}{l}\text { China Ranch, adjacent to main } \\
\text { parking area }\end{array}$ & Inyo & 35.799733 & -116.194892 & iNaturalist $5648539^{\mathrm{f}}$ \\
\hline Apr 2017 & $\begin{array}{l}\text { Amargosa River, } 3.7 \text { km S Old } \\
\text { Spanish Trail Hwy }\end{array}$ & Inyo & 35.817289 & -116.21411 & iNaturalist $5645134^{\mathrm{f}}$ \\
\hline Apr 2017 & $\begin{array}{l}\text { Amargosa River, } 3.7 \text { km S Old } \\
\text { Spanish Trail Hwy }\end{array}$ & Inyo & 35.817325 & -116.214076 & iNaturalist $5645137^{\mathrm{f}}$ \\
\hline Apr 2017 & $\begin{array}{l}\text { Amargosa River, } 4.4 \text { km S Old } \\
\text { Spanish Trail Hwy }\end{array}$ & Inyo & 35.810046 & -116.211608 & iNaturalist $5645143^{\mathrm{f}}$ \\
\hline Apr 2017 & $\begin{array}{l}\text { Amargosa River, } 1.4 \text { km S Old } \\
\text { Spanish Trail Hwy }\end{array}$ & Inyo & 35.836011 & -116.222668 & iNaturalist $5645177^{\mathrm{f}}$ \\
\hline Apr 2017 & $\begin{array}{l}\text { Amargosa River, } 750 \mathrm{~m} \mathrm{~S} \text { Old } \\
\text { Spanish Trail Hwy }\end{array}$ & Inyo & 35.841682 & -116.225401 & iNaturalist $5645175^{\mathrm{f}}$ \\
\hline Apr 2017 & $\begin{array}{l}\text { China Ranch Reservoir, China } \\
\text { Ranch }\end{array}$ & Inyo & 35.80505 & -116.18379 & LACM Herps $188785^{\mathrm{e}}$ \\
\hline Apr 2017 & $\begin{array}{l}\text { China Ranch Reservoir, China } \\
\text { Ranch }\end{array}$ & Inyo & 35.80505 & -116.18379 & LACM Herps $188786^{\mathrm{e}}$ \\
\hline Apr 2017 & $\begin{array}{l}\text { Amargosa River, } 4.0 \text { km S Old } \\
\text { Spanish Trail Hwy }\end{array}$ & Inyo & 35.81580 & -116.21164 & LACM Herps $188789^{\circ}$ \\
\hline
\end{tabular}




\section{APPENDIX A. CONTINUED}

\begin{tabular}{llllll}
\hline Date & General Location & County & Latitude & Longitude & Source \\
\hline Apr 2017 & $\begin{array}{l}\text { Willow Creek, downstream of } \\
\text { China Ranch }\end{array}$ & SB & 35.789746 & -116.199901 & iNaturalist $5633649^{\mathrm{f}}$ \\
May 2017 & $\begin{array}{l}\text { Ash Meadows National Wild- } \\
\text { life Refuge }\end{array}$ & Nye & 36.401093 & -116.274748 & iNaturalist $6409166^{\mathrm{f}}$ \\
Apr 2019 & $\begin{array}{l}\text { Ash Meadows National Wild- } \\
\text { life Refuge }\end{array}$ & Nye & 36.432697 & -116.310188 & iNaturalist 22147290 \\
Mar 2020 & $\begin{array}{l}\text { Ash Meadows National Wild- } \\
\text { life Refuge }\end{array}$ & Nye & 36.401542 & -116.273897 & iNaturalist $40312776^{\mathrm{f}}$ \\
\hline
\end{tabular}

a Inyo Co., California

b Nye Co., Nevada

c San Bernardino Co., California

${ }^{\mathrm{d}}$ Greene and Branston (2013)

${ }^{\mathrm{e}}$ Los Angeles County Museum of Natural History specimen number

${ }^{\mathrm{f}}$ Locations associated with iNaturalist records are available at https:/www.inaturalist.org/observations

$\mathrm{g}$ Location at which image in Fig. 2 was obtained 